\title{
The effect of organizational culture and work ethics on job satisfaction and employees performance
}

\author{
Achmad Faisal A. Sapada ${ }^{1}$, H. Basri Modding ${ }^{2}$, Ahmad Gani ${ }^{3}$, Syamsu Nujum ${ }^{4}$ \\ 1) (Doctoral Student in the Faculty of Economics, University of Muslim Indonesia) \\ 2, 3,4) (Faculty of Economics, University of Muslim Indonesia)
}

\begin{abstract}
-
This study explores the behavior of employees work done by testing and analyzing the influence organizational culture, work ethic and employee's performance with job satisfaction as a mediating variable. The population in this study was all employees who work in local government of Pinrang in South Sulawesi Province. There are 357 employees as a sample. We used Structural equation modeling (SEM) as research equipment. The result of this study provides evidence that the organizational culture and work ethic is proven to increase the perceived of employee job satisfaction. Good organizational culture and perceived of employee job satisfaction proven to improve employee performance. Results are shown in different work ethic in practice has not been able to improve the performance of employees. Perceived of employees job satisfaction proved able to act as a mediating variable in explaining the effect of organizational culture and work ethics on employee performance Keywords - organizational culture, work ethic, job satisfaction, employee performance
\end{abstract}

\section{INTRODUCTION}

Government in Indonesia in practice its implementation is always faced with problems both concerning the organization of government, government leaders, community governed, as well as the implementation of the functions of government, the principle of governance, environmental governance, system of government and government ethics, all of which require careful management for the purpose of government has announced it can be achieved efficiently and effectively. These variables in the execution turned out to require an understanding that is serious enough to achieve success, for it is proper if the parties in connection with the administration need to gain a better understanding and a comprehensive review of the knowledge-knowledge question (Djaenuri, 2015: 1). Achievement of the objectives of an organization can be manage in a professional and ready to meet the challenge by increasing reputation, existence, and the image of the organization through in-depth analysis and ongoing evaluation. In addition, it is also necessary in the wake of a conducive organizational climate. But the organization's climate is strongly influenced how the culture of an organization is managed. If there is a strong organizational culture, it will affect the behavior and performance of its members, in turn, will increase the success of the organization (Edison, et al., 2016: 117). Cultural organizations play an important role in the organization of government, because the organizational culture provides a framework related to employee behavior and work climate. If a strong organizational culture so employees in the organization considers the rule is no longer an obligation shackles, but has become a necessity of employees and organizations.

Other factors are also important in a government organization is the work ethic. Employees who strongly supports the work ethic is an employee who has a high commitment to the organization and subsequently more likely to make changes where such changes do not have the potential to change the basic values and goals of the organization and is considered beneficial for the organization, compared to employees who are less supportive work ethic and less committed to their organization that is more likely to make changes. Ethics need for working when people began to realize that progress in the field of business has led to people increasingly excluded from human values (humanistic), in a tight business competition that excels not only a company that has business criteria that good, but the company has ethics good business. The purposes of a government's own guidelines on ethical foundation for the apparatus related to the nature of power that tends to deviate. The power of government can only be implemented through law enforcement and ethics. At the same time the apparatus of government, especially government leaders also need to have a strong faith and high moral reference. Only the authorized capital such personalities, government officials can be developed further in order to build a more specific moral commitment to comply with the ethical values of the profession, manifestations of ethics adopted 
and implemented various social groups that differ from one another. Therefore ethics that describes the moral teaching and formation of character is always changing and evaluation of the community that supports it, as the dynamics of community life itself. The approach used in studying ethics, although he is moving dynamically, stays at the level of moral philosophy (normative ethics) and metha ethics. On the one hand, will give a moral justification frame and rejection of the merits of an attitude or action, on the other hand metha ethics appear to give meaning to all the assessment conducted by the formal philosophy (Djaenuri, 2015: 4).

Organizational culture and work ethic in a government affect job satisfaction and performance of local government officials. Some executives or leaders of the organization consider that the fulfillment of compensation, job satisfaction will follow. It is true because compensation is one of the important variables in the fulfillment and performance improvements. However, in reality there are also employees who are less satisfied although the standard of their needs are met, this could be for instance because he felt alienated, isolated in various ways, or treated unfairly by his superiors, or even its existence is not considered important by other employees, causing a sense of frustration. If this condition lasts for a long time, the effect will be difficult to repair; it can even lead to lethargy and low performance. Pinrang is the one of districts in the province of South Sulawesi, based on the observations found high intensity of the offenses committed by employees of Local Government, one of the most common violations are committed disciplinary offenses employees during working hours. Employees often come too late, they do not have a sense of responsibility to come to the office in a timely manner, and it is strongly associated with the ethics of each employee. An employee who has ethics should feel embarrassed when I have come late to the office, but in fact, many employees still arrive late, and they do not feel guilty with the action. Besides the issue of discipline, many employees who do not do their work effectively and efficiently. Most of those who do the work just to abort an obligation. They do a job without any sense of a caring attitude on the end result. This is indicated by the number of employees who work only so long. When they were asked to explain archive or file in question, the employee cannot do it. It showed a lack of sense of responsibility which is owned by the employee to work and is strongly related to the performance of each employee concerned. On several occasions found any employee who leaves a job for personal affairs in working hours. This is shown by the low intensity of services provided to the people who need the service at government offices. Some employees only come to be absent in the morning after an exit permit for personal business until late afternoon. The lack of a sense of responsibility which is owned by employees to be one cause of this state, and the sense of responsibility is related to the ethics of each employee.

\section{LITERATURE REVIEW AND HYPOTHESIS DEVELOPMENT}

\subsection{Organizational Culture}

Organizational culture is what is perceived by members of the organization so that perception creates a pattern of beliefs, values and expectations (Ivancevich et al., 2007: 181). Organizational culture explains a few things, first is the culture is perception, not something that can be touched or seen physically, but the employees understand it based on what they experienced in the organization. Second, organizational culture is descriptive, namely in terms of how the members receive and interpret the culture, regardless of whether they like it or not. Lastly, although the people in the organization have different backgrounds and work at different levels of the organization that also, they tend to interpret and express the organization's culture in the same way. This is the aspect of acceptance shared (Robbins \& Coulter, 2009: 26).

Measurement of organizational culture can be demonstrated through multiple dimensions,(Edison, et al., 2016: 131) namely; First, self-awareness, that members of the organization with awareness work to get satisfaction from their work, develop themselves, obey the rules, as well as offering quality products and high service. Second, the aggressiveness that members of the organization set goals that is challenging but realistic. They set the strategic plan and work to achieve that goal and pursue it with enthusiasm. Third, the personality that members be respectful, friendly, open, and sensitive to the satisfaction of the group and was very attentive to the aspects of public satisfaction (customers), either internal or external customers (each internal section should serve not be served). Fourth, the performance, that members of the organization have the value of creativity, meets the quantity, quality and efficiency. Fifth, the team organization, that members of the organization do a good cooperation and communication and effective coordination with the active involvement of the members, who in turn receive high satisfaction results as well as a shared commitment. The findings of the previous researchers provide evidence that a good organizational culture proven to improve individual job satisfaction (Vick Jackson, 2011; Sumantri, 2011; Sabri et al., 2011; Melina Taurisa \& Intan, 2012; Crispen Chipunza \& Bulelwa Malo, 2017). Good organizational culture proven to improve individual performance (Sumantri, 2011; Melina Taurisa \& Intan, 2012; Biswas, 2015). 
$\mathrm{H}_{1 \mathrm{a}} \quad$ organizational culture positive and significant effect on job satisfaction

$\mathrm{H}_{1 \mathrm{~b}} \quad$ organizational culture positive and significant effect on employee performance

\subsection{Work ethic}

Work ethics can be interpreted as a gesture of personality, temperament, character and belief in something. This attitude is not only owned by individuals, but also by other groups, and even the public. Ethics established by habit, the influence of culture and value systems that are believed (Tasmara, 2002:56). Work ethic has many elements: sourced and are associated with the values of a person's psychological, shows ingrained view, shows the attitude and hope someone (Wijayanti, 2012: 113). Ethos is the character and attitudes, habits and beliefs and so on that is special about the individual or group of people. Ethos can be interpreted as referring to the meaning of ethics or morals are morals that essential quality of the human person or group, including a nation. Ethos also means ethos human group of her developing nations view with respect to the good and bad which is ethics (Madjid, 2010: 89).

Employee performance is strongly influenced by the work ethic and discipline employees. If government officials are already getting used to the discipline in all things, so any work that would soon sorted out and well ordered, so that indirectly will improve a good work ethic. With a good working discipline, any government officials will always keep his job well and would not let her work abandoned. With the implementation of this attitude, it will be satisfactory service to the community so that people will find it all in the care of their needs in relation to government. If a local government official has the work ethic and discipline is high, it will have a positive impact on the employee's performance. The point is that the employee's performance will be run in accordance with the objectives expected because of the work ethic and discipline has been applied so that each work will be carried out effectively and efficiently (Febriyanto, 2012; Herlambang, 2013). Performance of employees will increase if supported by a solid team work (Hodges, 2015: 34).

The work ethic of employees is normative rules containing a system of values and moral principles as a guideline for employees in performing job duties within the company. Aggregation of ethical behavior of employees who work a picture of the employee in the company's ethics. Because the normative is derived from business ethics. Consequently ethics are not applied or intended for employees only. This means that the management policy concerning employee should also ethical, such as fairness and openness in terms of compensation, career and evaluation of employee's performance. So every ethical decision in the company is not only linked to the interests of management but also employees. The work ethic is the attitude, outlook, habits, traits or characteristics of how to work a person, a group or a nation (Tasmara, 2000: 14). Work ethics is the ethical character of government employees will work together in the corridor that is complementary, foster fair dynamics within the organization. Such as: Accommodating, sensitive, responsive, and proactive. The study of ethics has been done by scholars, that work ethic positive and significant effect on job satisfaction (Rokhman 2010; Marri et al., 2012). Good work ethic proved capable of improving the performance of the individual (I Wayan Marsalia Indica, 2011; Ridwan, 2013; Syahrul Nizam et al., 2016). Different results are shown other scholars that). Good work ethic proved unable to improve individual performance (Shafissalam \& Misbahuddin Azzuhri, 2014).

$$
\begin{array}{ll}
\mathrm{H}_{2 \mathrm{a}} & \text { Work ethic positive and significant effect on job satisfaction } \\
\mathrm{H}_{2 \mathrm{~b}} & \text { Work ethic positive and significant effect on employee performance }
\end{array}
$$

\subsection{Job Satisfaction}

In some cases in labor relations is often seen opposite between employees and management that led to the strike. Frustration that accompanies the performance of dissatisfaction can lead to aggressive behavior rather than withdrawal. Aggressive action could take the form of sabotage, deliberate wrongdoing, as well as the activities of the militant trade unions as irresponsible strikes, work delays and excessive protests. So, a lot of fights and feuds among the workers when they are very frustrated. When the aggressive actions to interfere in the course of the work, lowering the quality of production, as well as prohibit work together and in groups, they would show costly for the organization. Dissatisfaction Because of inadequate compensation or drudgery can also support incidents of theft by workers. Steal money, equipment, and inventories by workers are a critical issue for organizations (Wesley \& Yukl, 2005: 157). Job satisfaction Refers to a person 'general attitude toward his or jobs (Robbins \& Coulter, 2009; 301). Other scholars put forward the view job satisfaction is how an employee felt the job (Wexley \& Yukl, 2005). Job satisfaction positive and significant effect on employee performance (Melina Ratnawati Taurisa \& Intan, 2012). 
$\mathrm{H}_{3} \quad$ Job satisfaction positive and significant effect on employee performance

\subsection{Employee performance}

Performance management can be defined as a systematic process for improving organizational performance by developing the performance of individuals and teams (Armstrong, 2006: 1). Thus, it can be interpreted that the optimized performance and stable, not something accidental. Certainly, it is through the stages with a good performance management and maximum effort to achieve it. Individual performance can be measured (Miner, 1988) with; First, the quality of work by looking at the error rate, the extent of damage and accuracy in work; Secondly, the quantity, the number of jobs generated; Third, the use of time in the work indicated by absenteeism, tardiness, effective working time / working hours lost; Fourth, cooperation with others in the works. Empirical facts provide evidence that job satisfaction is able to act as intervening variables in analyzing the influence of organizational culture on company performance (Biswas, 2015).

$\mathrm{H}_{4 a}$ Work ethic positive and significant effect on employees performance as a mediating role of job satisfaction

$\mathrm{H}_{4 b} \quad$ Organizational culture positive and significant effect on employees performance as a mediating role of job satisfaction

\section{LITERATURE REVIEW AND HYPOTHESIS DEVELOPMENT}

The approach used in this study is a quantitative approach. 357 local government employees spread over 36 offices of local government agency (SKPD) Pinrang (South Sulawesi - Indonesia) were used as a sample. A Structural Equation Model with the Analysis of Moment Structures ver. 21 as a research equipment was used to test the study hypothesis

\subsection{Respondent Characteristics}

\section{RESULTS}

Characteristics of respondents are the identity of respondents whose data can be shown in the following

Table: 1 Characteristics of Respondent

\begin{tabular}{|c|c|c|c|}
\hline \multicolumn{2}{|c|}{ Characteristics } & $\mathrm{F}(n=357)$ & $\%$ \\
\hline \multirow[t]{2}{*}{ Gender } & Male & 214 & 59.94 \\
\hline & Female & 143 & 40.16 \\
\hline \multirow{4}{*}{ Age } & $<35$ & 35 & 17.33 \\
\hline & $36-45$ & 75 & 37.13 \\
\hline & $46-55$ & 65 & 32.17 \\
\hline & $>56$ & 27 & 13.36 \\
\hline \multirow{4}{*}{ Educational level } & Secondary, High School & 99 & 27.73 \\
\hline & Diploma & 52 & 14.57 \\
\hline & Bachelor & 181 & 50.70 \\
\hline & Master & 25 & 7.00 \\
\hline \multirow{7}{*}{ Echelon (Position) } & II-a & 1 & 0.28 \\
\hline & II-b & 14 & 3.92 \\
\hline & III-a & 16 & 4.48 \\
\hline & III-b & 21 & 5.88 \\
\hline & IV-a & 71 & 19.89 \\
\hline & IV-b & 25 & 7.00 \\
\hline & Non Echelon & 209 & 58.55 \\
\hline
\end{tabular}

Respondents of this research is gender characterized by male of $214(59.94 \%)$, the level of education is dominated by personnel with the Bachelor as much as 181 respondents $(50.70 \%)$, respondents in general do not have the echelon (Non echelon) of 209 respondents $(58.55 \%)$. 


\subsection{Variables description}

4.2.1. Organizational culture

Organizational culture is a normative philosophy deeply rooted habit in advancing government organizations. Indicators of organizational culture in this study are: (a) self-awareness which is the attitude of employees who are always trying to develop themselves and their capabilities, how the local government officials to obey the rules that exist, and how the local government officials to make efforts to provide the best service , (b) aggressiveness is a condition in which the employee is considered full of initiative in doing the task, employees do not always depend on the user employer, employees set a plan of work and trying to finish well. (c) Personality is a characteristic of employees who help in completing the work, the employee mutual respect for differences of opinion, mutual respect among fellow employees in each work unit. (d) Performa is a condition in which employees put quality in finishing the job, employees are always innovating to find new things and useful, every employee is always trying to work effectively and efficiently. (e) The orientation team is a state in which each of the tasks performed by a team of discussion, any problems in the working team has always done well, the success of the work is the success of the work team. Results of respondents on average obtained a value of 4.10. The average value and the loading factor shown in the following table:

Table:2 Organizational cultures (Mean variables and loading factor)

\begin{tabular}{|ccc}
\hline Indicator variables & Mean & LDF $(\lambda)$ \\
$\mathrm{X}_{11}$ & 3.99 & 0.722 \\
$\mathrm{X}_{12}$ & 4.14 & 0.888 \\
$\mathrm{X}_{13}$ & 4.11 & 0.722 \\
$\mathrm{X}_{14}$ & 4.11 & 0.605 \\
$\mathrm{X}_{15}$ & 4.13 & 0.554 \\
\hline
\end{tabular}

\subsubsection{Work ethic}

The work ethic of individuals (leaders) were demonstrated through ethical good appreciation of the individual (the leader) can establish itself as a commitment to make an example of goodness and morality government to fellow employees or subordinates. Indicators measuring the work ethic in this study are: (1) Accommodative is the willingness of individuals (leaders) to accept criticism, and suggestions from various parties so hopefully people (leaders) continues to provide the services properly. (2) Sensitivity is the ability of individuals (leaders) to understand developments in the vicinity, individuals (leaders) understand what is needed partners (subordinates) and able to be the first to give attention to the surroundings. (3) Responsiveness an individual respondents to the (leader) for constantly trying to serve people with serious, individuals (leaders) are required to play an active role in responding to the aspirations of the people, and not just hear the proposals but followed up with action. (4) Proactive is a condition in which individuals (leaders) always anticipate the events of harm that would arise in the working area, individuals (leaders) have always participated in every activity / activities office, and individuals (leaders) always maintain an atmosphere conducive to a variety of party. Results of respondents on average obtained a value of 4.16. The average value and the loading factor shown in the following table:

Table:3 Work ethic (Mean variables and loading factor)

\begin{tabular}{ccc}
\hline Indicator variables & Mean & LDF $(\lambda)$ \\
\hline $\mathrm{X}_{21}$ & 4.19 & 0.606 \\
$\mathrm{X}_{22}$ & 4.28 & 0.650 \\
$\mathrm{X}_{23}$ & 4.13 & 0.815 \\
$\mathrm{X}_{24}$ & 4.04 & 0.770
\end{tabular}

\subsubsection{Job Satisfaction}

Job satisfaction is employee attitudes shown towards their work. This attitude comes from the perception of employees about his work. Indicators of job satisfaction in this study were: (1) Wages represent a state in which employees feel their salary is feasible, employees feel accepted benefits in addition to salary is feasible, employees are satisfied with the well-being given. (2) Work is a state in which employees feel the work carried out interesting and fun, employees feel given the widest possible opportunity to study, employees feel given the 
responsibility of the job. (3) promotion opportunities is a state in which employees feel conducted in a transparent promotion system, promotion is based on merit, promotion opportunities are open to all employees without discrimination. (4) Leadership is a state in which employees expect leaders to always show concern and give advice to employees, leaders praised the employees if achieving good work, leadership always helps employees if in trouble at work. (5) co-workers is a state in which the employee looked at co-workers have a desire to help in the work, coworkers fun and be responsible for their work, co-workers always give impetus to perform their jobs well. Results of respondents on average obtained a value of 3.99. The average value and the loading factor shown in the following table:

Table 4. Job satisfaction (Mean variables and loading factor)

\begin{tabular}{ccc}
\hline Indicator variables & Mean & LDF $(\lambda)$ \\
\hline $\mathrm{Y}_{11}$ & 3.98 & 0.729 \\
$\mathrm{Y}_{12}$ & 3.94 & 0.775 \\
$\mathrm{Y}_{13}$ & 4.07 & 0.473 \\
$\mathrm{Y}_{14}$ & 3.94 & 0.805 \\
$\mathrm{Y}_{15}$ & 4.00 & 0.807
\end{tabular}

\subsubsection{Employee performance}

Employee performance is the result of a process of employee work done and measured over a certain period of time under the provisions or agreements that has been designated. The measurements include: (1) the target is a condition in which the employee based on the targets to be met or completed, employees feel a given target is very challenging but realistic, and employees meet the quantity has been targeted. (2) Quality is a condition in which employee's feel of quality set is in conformity with the standards, employees have the commitment of quality, and employees have procedures for quality achievement. (3) Time is a condition in which the clerks finish the job on time, the public satisfied with the service given time employee, the employee is committed to the importance of punctuality. (4) Obey principles is a condition in which the employees do the job the right way, employees do work with transparent, employee unable to account for the results of his work. Results of respondents on average obtained a value of 4.07. The average value and the loading factor shown in the following table:

Table:5 Employee's performance (Mean variables and loading factor)

\begin{tabular}{ccc}
\hline Indicator variables & Mean & LDF $(\lambda)$ \\
\hline$Y_{21}$ & 4.12 & 0.577 \\
$Y_{22}$ & 3.94 & 0.826 \\
$Y_{23}$ & 4.07 & 0.805 \\
$Y_{24}$ & 4.14 & 0.830
\end{tabular}

\subsection{Goodness of Fit}

The model test results are evaluated based on the goodness of fit indices with the criteria presented models as well as critical values that have compatibility data.

Table:6 Goodness of fit indices overall model

\begin{tabular}{cccc}
\hline Goodness of fit index & Cut-off Value & Results Model ${ }^{*}$ & Description \\
\hline$\chi^{2}-$ Chi-square & small Expected & $126.098<(0,05: 102=126.574)$ & Good \\
Probability & $\geq 0.05$ & 0.053 & Good \\
CMIN/DF & $\leq 2.00$ & 1,236 & Good \\
RMSEA & $\leq 0.08$ & 0.026 & Good \\
GFI & $\geq 0.90$ & 0.963 & Good \\
AGFI & $\geq 0.90$ & 0.938 & Good \\
TLI & $\geq 0.92$ & 0,990 & Good \\
CFI & $\geq 0.92$ & 0.993 & Good
\end{tabular}

Evaluation of the eight criteria model shows a goodness of fit indices, on the whole can be said to have been in accordance with the data and can be analyzed further. 


\subsection{Hypothesis testing}

Based on the empirical models proposed in this study can be tested against the hypothesis put forward by testing the path coefficients in structural equation modeling. Testing the hypothesis by looking at the value of probability, if the probability value (p-value) $<0.05$ then the significant influence of variables (Sjahruddin, H., \& Sudiro, AA, 2013). The test results are presented in the following table:

Table:6 Hypothesis Testing

\begin{tabular}{|c|c|c|c|c|c|c|}
\hline \multirow[t]{2}{*}{ Exogenous } & \multirow[t]{2}{*}{ Intervening } & \multirow[t]{2}{*}{ Endogenous } & \multicolumn{3}{|c|}{ Direct Effect } & \multirow{2}{*}{ annotation } \\
\hline & & & Standardize & critical ratio & $\mathrm{p}$-value & \\
\hline organizational culture & - & Job satisfaction & 0,411 & 7,161 & 0,000 & Significant \\
\hline organizational culture & - & $\begin{array}{l}\text { employee } \\
\text { performance }\end{array}$ & 0,295 & 4,845 & 0,000 & Significant \\
\hline work ethic & - & Job satisfaction & 0,449 & 6,617 & 0,000 & Significant \\
\hline work ethic & - & $\begin{array}{l}\text { employee } \\
\text { performance }\end{array}$ & 0,004 & 0,074 & 0,941 & Insignificant \\
\hline Job satisfaction & - & $\begin{array}{l}\text { employee } \\
\text { performance }\end{array}$ & 0,545 & 7,052 & 0,000 & Significant \\
\hline \multicolumn{4}{|c|}{ Indirect Effect } & critical ratio & $\mathrm{p}$-value & annotation \\
\hline Exogenous & Intervening & \multicolumn{2}{|c|}{ Endogenous } & & & \\
\hline organizational culture & Job satisfaction & \multirow{2}{*}{\multicolumn{2}{|c|}{$\begin{array}{l}\text { employee performance } \\
\text { employee performance }\end{array}$}} & 0,224 & 0,000 & Significant \\
\hline work ethic & Job satisfaction & & & 0,245 & 0,000 & Significant \\
\hline
\end{tabular}

\section{$H_{1 a}$ : Organizational culture has a positive and significant effect on job satisfaction}

Organizational culture has a significant positive effect on job satisfaction and probability value of $0.000<0.05$ with a coefficient equal to 0.411 , this coefficient indicates that the presence of a good organizational culture will create better job satisfaction. The study's findings support the results of previous studies that organizational culture positive and significant impact on job satisfaction (Sabri, 2011). The employees have a high work aggressiveness that an employee is always full of initiative in doing the task, employees do not always depend on superiors instructions when carrying out the task, each employee establishes employment plan and try to finish well. Problems in the work team always resolved, and the success of the work is the success of the team. Personality owned by employees and is represented by the willingness of employees to assist each other in completing the work and appreciate the differences between them as well, mutual respect among fellow employees. Employee's performance always put quality in finishing the job and constantly innovating and trying to work effectively and efficiently. Servants have high self-awareness is evidenced by the attitude that is always shown to develop the ability to work with respect to the existing rules and oriented to provide the best service.

\section{$H_{1 b}$ : Organizational culture has a positive and significant effect on employee performance}

Organizational culture has a significant positive effect on employee performance with p-value $=0.000>0.05$ with a coefficient value of 0,295 , this coefficient indicates that a good organizational culture resulted in better employee performance. This suggests that a good organizational culture will create higher employee performance; the findings are consistent with results of previous research studies that organizational culture influences on job satisfaction and employee performance (Sumantri, 2011). Employee always has the initiative in doing the task; employees do not always depend on the instructions of superiors. Each team assignments done with the discussions, problems that occur in the working team have always done well, and the success of the work is the success of the team. Such conditions have an impact on employee willingness to always put the quality in work, the desire to innovate. Employee continuously strives to develop themselves and obey the rules that exist, then oriented on providing the best service to the community.

\section{$\mathrm{H}_{2 \mathrm{a}}$ : Work ethic has a positive and significant effect on job satisfaction}

Work ethic has positive and significant effect on job satisfaction with the p-value $=0.000>0.05$ with a coefficient value of 0,449 , this coefficient indicates that the work ethic shown good results in a high employee with job satisfaction. This finding is consistent with the findings of previous investigators that professional organizations are working very hard to establish a code of conduct to help employees understand and manage their ethics and responsibility. Islam considers ethics as an important factor, because the ethics of a comprehensive, stable, fair, and historically proven in building a great society. Islamic work ethics that have a positive impact on job satisfaction (Marri et al., 2012). The condition is caused because the employee has the ability to understand the development around it, understand what is required of his subordinates, and able to be the first to pay attention to the surroundings. Individuals (leaders) are willing to accept criticism given, are 
willing to accept suggestions from various parties, and always try to serve it well. Servants always serve the public very seriously, Individual (leader) always anticipate the occurrence of adverse events and continues to maintain an atmosphere conducive to the various parties.

\section{$H_{2 b}$ : Work ethic has a positive and insignificant effect on employee performance}

Work ethic has a positive influence on employee performance is not significant with p-value $=0.941>0.05$ with a coefficient of 0.004 , the coefficient indicates that a good work ethic cannot improve the performance of employees. The employee work ethic has been unable to improve employee performance so that it takes care leaders to pay attention and look for other alternatives such as increasing job satisfaction. The results of this study rejected the findings of previous researchers that work ethic and positive affect performance significantly (Syahrul Nizam et al., 2016). Respondents have the ability to understand developments in the working environment, individuals (leaders) understand what is required of his subordinates, and able to be the first to give attention then always participate in every activity / activities office, and always maintain an atmosphere conducive to the various parties, however the reality has not been able to improve the performance of employees.

\section{$\mathrm{H}_{3}$ : Job satisfaction has a positive and significant effect on employee performance}

Job satisfaction has a significant positive effect on employee performance with p-value $=0.000>0.05$ with a coefficient value of 0,545 , this coefficient indicates that high job satisfaction resulting in an increase in the performance of employees. Employee job satisfaction perceived impact on the increase in the performance of employees. This finding is relevant to the results of previous studies that job satisfaction is positive and significant effect on employee performance (Melina Ratnawati Taurisa \& Intan, 2012; Kadir et al., 2017). Respondents feel that they have the opportunity to opt in to the promotion. My co-workers are very helpful in completing the work as well as fun and responsible then constantly motivate employees to produce high quality work. Feasibility salary received by an employee, additional income and the welfare of employees of the fairly. This condition cannot be separated from the role of leadership to always show concern and give advice to employees as well as on several occasions give praise to the employee, if the employee has reached the good work. The leadership must help when employees have difficulty in working.

\section{$\mathrm{H}_{4 \mathrm{a}}$ : Organizational culture has a positive and significant effect on employee performance, as a mediates job satisfaction}

Organizational culture has a positive and significant effect on employee performance, as a mediates job satisfaction. The probability value $=0.000>0.05$ with a coefficient of 0.224 , the coefficient indicates that their good organizational culture leads to high job satisfaction and then impact on the performance of employees is high. These results are relevant to the findings of previous investigators that organizational culture positive and significant effect on the performance of the company due to the support of employee satisfaction is high (Biswas, 2015).

\section{$\mathbf{H}_{4 \mathrm{~b}}$ : Work ethic has a positive and significant effect on employee performance, as a mediates job satisfaction}

Work ethic has a significant positive effect on employee performance, as a mediates job satisfaction and the value probability is $0.000>0.05$ with a coefficient of 0.254 , this coefficient indicates that support employee satisfaction impacts significant overall effect on the performance of employees work ethic. The findings are relevant to the results of previous studies that job satisfaction is felt capable of acting as intervening in analyzing the effect on the performance of the work ethic characterized by turnover (Rokhman, 2010).

\section{CONClusion}

Organizational culture which either are proven to increase job satisfaction, so it is getting better and organizational effective, it will increase job satisfaction and employee performance in carrying out its activities. Work Ethic shown clerks in practice proven to increase employee satisfaction, but on causality others are shown the results that the Work Ethic shown employee was not able to improve the employee's performance and so we need the support of the creation of job satisfaction are high so as to give full contribution to the creation of employee performance high. On the other hand, the perceived job satisfaction was found to improve employee performance. Job satisfaction is able to demonstrate its role as an intervening variable in explaining the influence of organizational culture and work ethic to improving the performance of employees. 
It takes a strong effort of the employees and the leadership of the local work unit to increase self-awareness, performance and personality so that they can show high levels of individual performance to provide maximum service to the community and sustainable. The work ethic of individual (leadership) should not be a mere toehold in carrying out his activities but is expected to be in considering the level of welfare of employees so as to increase job satisfaction, which in turn have an impact on employee performance improvement.

\section{REFERENCES}

[1]. Armstrong, Michael. (2006). A Handbook of Human Resource Management Practice. 10 ${ }^{\text {th }}$. Edition. London: Kogan Page

[2]. Biswas, W. (2015). Impact of Organization Culture on Job Satisfaction and Corporate Performance. Journal of Research in Humanities and Social Science, $3(8)$.

[3]. Crispen Chipunza \& Bulelwa Malo (2017). Organizational culture and job satisfaction among academic professionals at a South African university of technology. Problems and Perspectives in Management (open-access), 15 (2), 148-161. doi: 10.21511/ ppm.15 (2) .2017 .14

[4]. Djaenuri, Aries. (2015). Leadership, Ethics and Government Policy. Bogor: Publisher Ghalia Indonesia.

[5]. Edison, E., Anwar, Y., \& Komariyah, I. (2016). Human Resource Management: Strategies and changes in order to improve the performance of employees and organizations. Bandung: Alfabeta

[6]. Febriyanto, Setyo Ditto. (2012). The influence of Islamic Work Ethics, Organizational Commitment Against Managerial Performance

[7]. Herlambang, Reza. (2013). Influence on Performance of Managerial Work Ethics

[8]. Hodges, C. (2015). Law and Corporate Behavior: Integrating Theories of Regulations, Enforcement, Compliance and Ethics. Bloomsbury Publishing.

[9]. I Wayan Marsalia Indica. (2011). The influence of Islamic Work Ethics and Transformational Leadership Style and Organizational Commitment Toward EmployeePerformance.

[10]. Ivancevich, John M, Robert Konopaske \& Michael T Matteso, (2007). Behavior and Management, Seventh Edition, Jakarta. , Erland.

[11]. Kadir, A., Sjahruddin, H., \& Purnomo, S. H. (2017). Pengaruh karakteristik pekerjaan dan kompensasi terhadap kepuasan kerja Organization and Management Journal. Issue 2 October. 62-75

[12]. Majid, N. (2010). Religious Society, Bringing Values of Islam in Life. Jakarta: Dian Rakyat.

[13]. Marri, MYK, Sadozai, AM, Zaman, HMF, and Ramay, MI (2012). The impact of Islamic work ethics on job satisfaction and organizational commitment: a study of agriculture sector of Pakistan. International Journal of Business and Behavioral Sciences, 2 (12), 32-45.

[14]. Melina Taurisa, C., \& Intan R. (2012). Analysis of the influence of organizational culture and job satisfaction on organizational commitment in improving employee performance (Study at PT. Sido Appears Kaligawe Semarang). Journal of Business and Economics, 19 (2).

[15]. Miner, John B. (1988), "Organizational Behavior: Performance And Productivity". First Edition, Random House Business Division, New York

[16]. Ridwan. (2013). The role of Islamic Work Ethics to Locus Of Control Relationship with Employee Performance.

[17]. Robbins, Stephen P \& Mary Coulter (2009). Management. Pearson. United State America. Eighth Edition Volume 2.

[18]. Rokhman, W. (2010). The effect of Islamic work ethics on work outcomes. EJBO-Electronic Journal of Business Ethics and Organization Studies.

[19]. Sabri, PSU, Ilyas, M., \& Amjad, Z. (2011). Organizational culture and its impact on the job satisfaction of the University teachers of Lahore. International Journal of Business and Social Science, 2 (24).

[20]. Shafissalam, Alfa \& Misbahuddin Azzuhri. (2013). Influence of Islamic Work Ethic To Performance Employees Cooperative Agro Niaga Indonesia (KaniNDO) Sharia, East Jakarta. Student Science Journal of Business Economics Faculty

[21]. Sjahruddin, H., \& Sudiro, AA (2013). Organizational justice, organizational commitment and trust in manager as predictors of organizational citizenship behavior. Interdiciplinary J. of contemporary Res. Bus. (IJCRB), 4 (12), 133-141.

[22]. Sumantri. (2011). Influence Leadership, Organizational Culture and OCB on Job Satisfaction and Employee Performance of Islamic Banking Jakarta.

[23]. Syahrul Nizam bin Salahudin., SS binti Baharuddin. Abdullah, MS, and Osman, A. (2016). The Effect of Islamic Work Ethics on Organizational Commitment. Procedia Economics and Finance, 35, 582-590.

[24]. Tasmara, Toto. (2000). Towards a devout Muslim: explore your own potential. Jakarta. Gema Insani.

[25]. Tasmara, Toto. (2002). Cultivating Islamic Work Ethics, Jakarta: Gema Insani Press.

[26]. Vick Jackson. (2011). Affect of Satisfaction, Organization Commitment, Professionalism toward bahavior Citizenship Organization and Performance by Staff Industry.

[27]. Wexley, Kenneth N \& Gary A. Yukl, (2005). Organizational Behavior and Psychology Company, Interpretation: M. Shobarudin, Jakarta: Rineka Reserved.

Note:

Since Camera Ready copy of the paper is final one, no further modification is entertained. So please make sure that the contents and format is fit for the Journal.

Achmad Faisal A. Sapada" The effect of organizational culture and work ethics on job satisfaction and employees performance." The International Journal of Engineering and Science (IJES), vol. 6, no. 12, 2017, pp. 28-36. 